
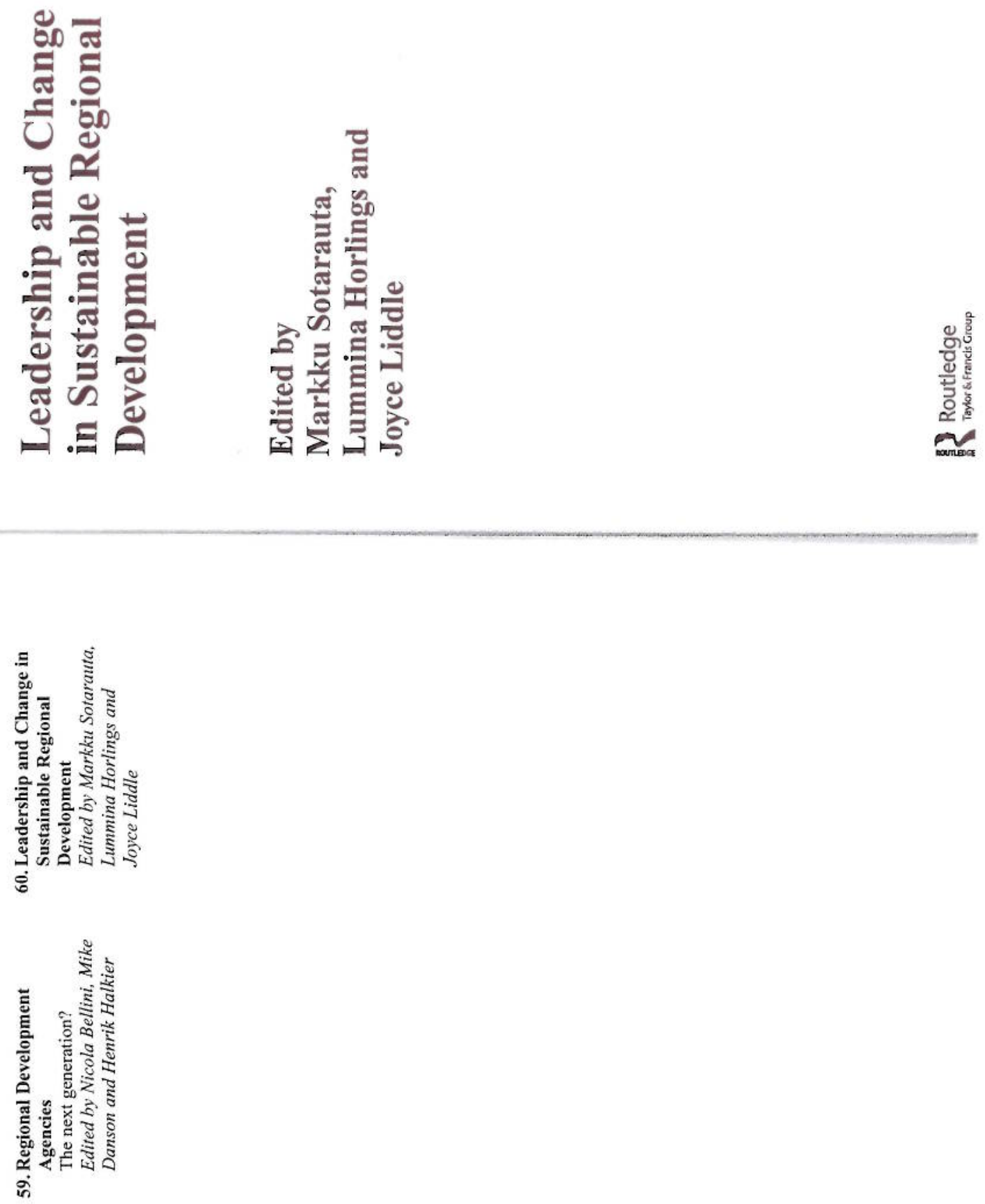


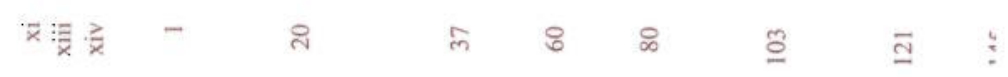

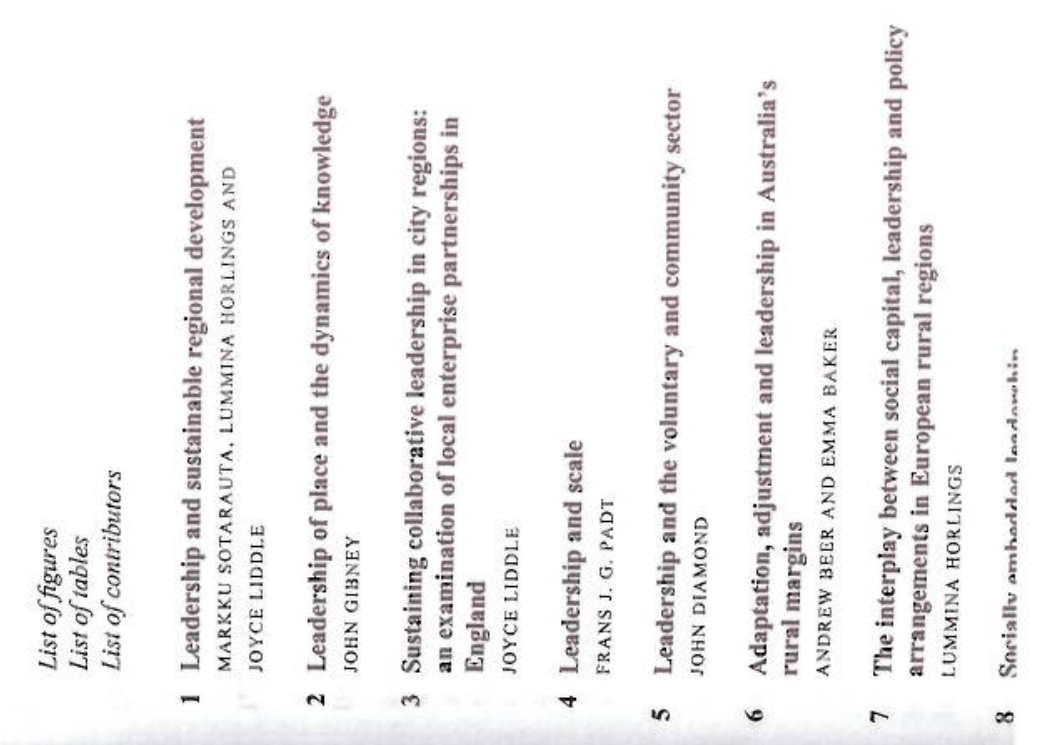

产

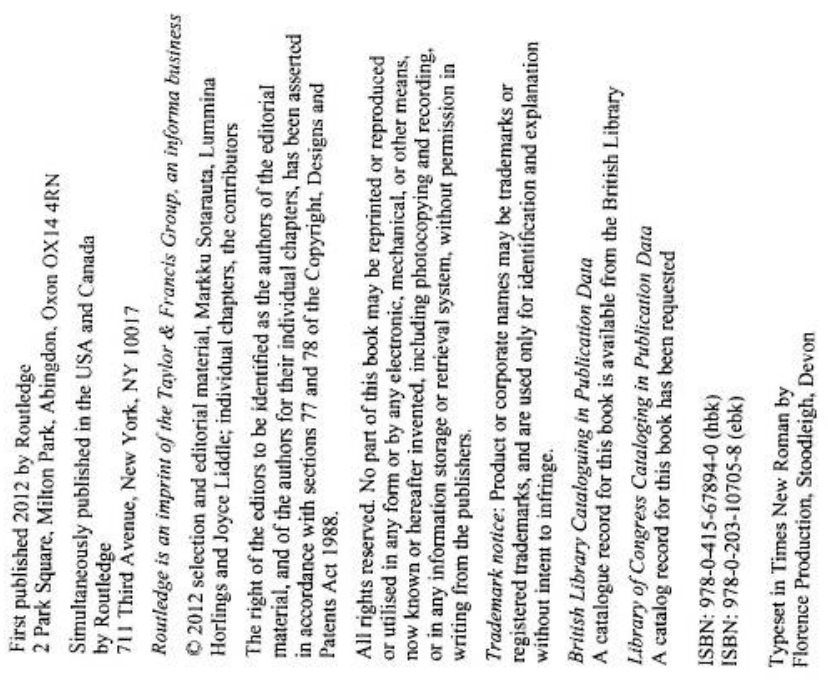

(3) 


\title{
5 Leadership and the voluntary and community sector
}

\author{
John Diamond
}

\section{Introduction}

The UK has seen a significant increase in the voluntary and community sector over the past thirty years. Since 1997 there has been an increase in the direct funding of 'leadership' initiatives for the voluntary and community sector (VCS) across the UK (Balloch and Taylor, 2001; Birch and Whittam, 2008; Craig and Taylor, 2002; Diamond, 2008; Purdue, 2007).

The New Labour government commissioned and funded a number of programmes to directly enhance the managerial and technical skills and capacities of individuals working in the sector. According to the latest data on the VCS in the UK (Clark et al., 2011), the full-time equivalent workforce is 617,000 of whom 43,000 are managers. More than 37 per cent of the workforce have a degree or higher and senior staff are the ones who are most likely to receive training. Since 2001 the work force has increased by 40 per cent.

We can observe over the past decade how the direct investment in these infrastructure organisations has often resulted in merging of identities between City Hall decision makers and Third Sector professionals. As a consequence, at a local or neighbourhood level we can see a growing distance or separation from streetor community-based groups and these VCS infrastructure agencies. Alongside these subregional or city-based agencies there has been an investment in regional organisations too. In a number of ways we can see a similar merging of identities between policymakers at the regional level and "leaders" from the VCS at the regional level too. This paper draws upon empirical work undertaken in the northwest of England with leaders and managers from the VCS to look at the ways in which individuals seek to balance competing needs and pressures (Diamond and Pearce, 2010; Martikke and Tramonti, 2005; Peck and Ward, 2002). In particular, it is possible to see how individuals with very clear and embedded roots in community politics and activism react to these competing pressures to conform and meet the demands and needs of regional policymakers/practitioners/funders. Their role and contribution of the academy to these processes is reflected in the chapter too. The author is part of a team developing and providing post-graduate education in leadership and management for VCS managers/decision makers/

This char the different the sector; $j$ historical, $\mathrm{p}$ there is an experiences different (an to observe alliances of In this chi five years; initiatives; changes adc

\section{Categorisi} communit

The followi in which 'le five years , Manchester (over time) how the co attempts to and econon tions below, and functio priorities of separate dis

- Politica to the politici with lor to enab 1980s 1

- Single justice/ social c to link througl and thi 
activists. Through reflections on practice, the chapter seeks to sketch out the potential to support innovative ways of working and thinking among a key group of activists/managers.

This chapter will attempt to show the relationship between neoliberalism and the different ways in which leadership is valued, promoted and understood across the sector; it is important too to locate the particular debates in their sectional, historical, political (and often times geographical) settings. In other words, while there is an overarching ideological framework within which the different experiences and models of leadership across the VCS are located, there will be different (and sometimes contradictory) narratives and interpretations. It is possible to observe two different sets of relationships being formed and developed alliances of convenience or networks of politically active individuals.

In this chapter we trace the changes in governmental policy over the past twentyfive years; examine the contradictions and tensions present within these policy initiatives; identify different strategies and approaches; and reflect upon the changes adopted.

\section{Categorising activists/leaders in the voluntary and community sector}

The following categories are offered as a way of conceptualising the different ways in which 'leadership' is valued and understood. They are drawn from over twentyfive years of working in and with the Voluntary and Community Sector in Manchester and across the north-west of England. In part, they illustrate the growth (over time) of the significance that has been attached to ideas of 'leadership' and how the concept (or definition) of 'manager' has changed too, as the chapter attempts to demonstrate how these changes in definition reflect important political and economic changes within the VCS and society. In arriving at the categorisations below, I am aware that they offer a 'snapshot' of the roles, political ideologies and functions that individuals and agencies have identified as representing the priorities of the sector over time. They are offered here as a way of drawing together separate discussions on ideology, function and values, which are discussed below.

- Political/Social/Community Activist - working with local groups in opposition to the local state: Developed through the 1960 s to mid 1980s - highly politicised with an explicit commitment to social and political change; working with local groups influenced by community development practice and seeking to enable local/neighbourhood groups to influence change locally - in the late 1980s possible move into local government or local state-run agencies;

- Single Issue Activist - working with specific groups (environmental/social justice/housing/equalities) or Faith groups with an explicit commitment to social change and a commitment to ethical or social justice questions; sought to link local and global especially through environmental pressure groups or through international aid organisations (OXFAM) - active in mid to late 1980s and through late 1990s in aftermath of World Trade discussions and the 
development of opposition to globalisation - providing an important network to support the Occupy Now movement;

- Social Enterprise/Social Entrepreneurs - developed and supported by Labourrun local authorities in the 1980s and funded through the 1990s by both Labour and Conservative governments - seen now to represent alternative social and welfare providers and represent a market dominated by former single-issue charities (involved in housing/homelessness/children); promoting different social and economic responses to needs of communities - likely to be more pragmatic than political;

- Brokers and Fixers - development of organisations that trade upon their knowledge and understanding of the finances available and the priorities set by government - use networks with the European Union - bring together different partners or agencies to meet the requirements of available funding;

- Networks and Partnership facilitators and managers - growth in 'independent' agencies that emerged out of the subregional and city-based bodies established to support the VCS; largely aimed at working within a geographical patch and attempting to support agencies through a membership and subscription basis - likely successor to those national agencies that the current UK government are cutting back on - likely to represent the dominant form of VCS support over the next 5-10 years;

- Independent and loose networks and alliances campaigning to oppose the current government's cuts and austerity package - membership drawn from across the categories above but practice suggests a diverse pattern of membership with newer and young members plus older ones drawn from the generation of political and community activists of the late 1960s/early 1970s.

\section{Setting the context}

For nearly twenty-five years in the UK successive governments have attempted to promote the role of voluntary and community-based organisations as part of the network of local leaders who are expected to work cooperatively with political and business leaders but whose legitimacy and status is dependent upon their sponsorship and goodwill (Banks and Shenton, 2001; Blakely and Evans, 2008; Blunkett and Jackson, 1987; Craig et al., 1999; Mayo, 1997). As this chapter attempts to illustrate, there are a number of inherent tensions within the relationships between those in a leadership role in the voluntary and community sector and those in the political, administrative and business elites (at either a local or national level). The particular form these tensions take will vary over time as well as reflecting the nature of the tensions and the specific material conditions in each locality and place. But, they will involve clashes over resources or the values of sponsoring agencies when these are in conflict with VCS organisations. They are, therefore, a way of understanding the nature and form of the power dynamics present at the local, regional or national level.

We can locate the emergence across political parties and civic institutions in the idea of supporting and promoting a voluntary sector leadership as part of a 
network

\section{Labour-}

h Labour cial and gle-issue different be more

Ion their riorities together funding; pendent' ablished al patch scription ent UK form of

jose the wn from of memrom the y 1970 s.

tempted part of jolitical on their s, 2008; chapter elationy sector local or as well in each alues of hey are, namics

tions in art of a broader neoliberal restructuring of the state. At a very simple level this discovery and promotion of the voluntary and community sector by political parties and civic institutions coincided with the social and economic restructuring of the late $1980 \mathrm{~s}$ onwards (Chesters, 2010; Davies, 2007; Diamond, 2001; Harvey, 2000, 2010; Wainwright, 2003).

As is suggested below, the voluntary and community sector in the UK were seen as an important part of the restructuring of the relationships between the political institutions of the state and those social and welfare agencies that provided education, health, housing, welfare benefits and social services from the mid 1970s onwards. As part of this process, voluntary and community-based organisations received limited state funding to provide some elements of locally based social and welfare services. The period after 1997 can be seen as marking a step change in these processes. A key part of the New Labour reform agenda was the 'modernisation' of local government. The changes introduced here can be understood as representing an attempt to restructure the political and institutional arrangements at the local level. An explicit aspect of these changes was the role and future of the voluntary and community sector at the local level.

Since 1997 the form this promotion took changed qualitatively. There were a number of deliberate policy and political choices taken by the New Labour government that were aimed at supporting those in a leadership role in voluntary and community-based organisations (Byrne, 2001; Dale, 2002; HMSO, 1998; Pierson, 2008). At the same time a number of key charities in the UK established their own initiatives aimed at supporting individuals who might be regarded as future leaders. Both of these approaches demonstrated a commitment to identify, support (sponsor) and ensure investment in the capacities and skills of future or potential leaders within the sector. The significance of these decisions and ways of working is examined below but, in essence, it represented a deliberate move away from the collective or collaborative models of leadership that were present in the sector to a highly individualised conventional and personalised model of leadership.

\section{Changes in governmental policy}

There have been a number of important changes in UK governmental policy over the past twenty-five to thirty years in the ways in which the relationship(s) between the state and the voluntary and community sector have been defined and constructed. Specifically, the VCS is seen as a necessary component part of those agencies - commissioned by the state to provide social and welfare services working with a range of service users in neighbourhoods where state-funded agencies were seen to have 'failed'. (Burgess et al., 2001; Boddy and Fudge, 1984; Craig et al., 1999; Diamond, 1991; Diamond and Nelson, 1993; Leach and Wilson, 1998; Wainwright, 1987).

These developments are important and can be seen as illustrating a broader set of social and political changes taking place in the UK over this past twenty-five to thirty years. They can be seen both as a consequence of significant shifts in 


\section{John Diamond}

social and economic policy and as part of the process of political change to create a new discourse on the role of the state. In other words, these changes to the role and relationships of the VCS with the state reflect both a reaction to and a consequence of the changes, as well as representing a potential catalyst for a longerterm impact.

The changes in UK government policy in respect of welfare and public agencies date back to the late 1970s. The (then) Labour government began to cut public and welfare spending. The primary areas of concern were education (especially higher education), health and social welfare. While these cuts did meet with some resistance, the election in 1979 of the Conservative government led by Margaret Thatcher saw a continuation of these policies with a much more deliberate and focused attempt to recast the relationship between the state, the individual and the market. The reaction to and role of the VCS in this period is important to reflect upon because (as I argue below) it is during this period that we can observe the emergence of a new thinking on the role and place of 'leadership' within the VCS.

There is a clear recognition within the VCS and between those engaged in working with the VCS that simple and straightforward categorisations of the VCS are difficult to arrive at. There are a number of working definitions that practitioners/researchers can draw upon and they usually reflect the following:

- the geographical location within which the organisation operates (from local to national);

- the size of the organisation, including staff numbers as well as turnover;

- the remit/rationale/identity of the organisation from faith based to issue based;

- the values and focus of the organisation.

In addition, there are other variables or factors that can be included involving the management structure of the organisation and the extent to which it is registered as a charity or not for profit organisation. Over the past fifteen years years the criteria for registration have changed and as a result there are many more agencies described as being part of the VCS. These variables are clearly important if you are seeking to develop a shared language of both practice and analysis or if you are wishing to develop a way of understanding how concepts of leadership are understood within the sector. In essence, the model of leadership present in the VCS mirrored that in the wider society. Those VCS organisations that sought to develop collective or participatory practices were seen as marginal. The whole central government investment programme focused upon valuing and developing single 'leaders' rather than collective approaches.

In the UK there are a number of VCS organisations that have a long history of providing social and welfare services to the most vulnerable. Many of these organisations are faith based - some are attached to particular religious groups, while a number are not. But they share a history in the sense that they were established to provide something the state did not. Over time, they have become 
1 create

he role and a longer-

;encies public ecially 1 some irgaret te and al and ant to sserve within yed in of the $s$ that ing:

local

r; rased;

ig the tered s the ncies f you or if rship nt in ught hole ping

ry of hese ups, vere ome part of the mix of state-funded or state-coordinated welfare provision. But their formation, development and continued existence did not (and does not in and of itself) reflect a broader critique of society and the politics of decision making at the local level. It is here that we can begin to understand more fully the nature of the relationships between local VCS organisations and the state.

Through the 1960s/early 1970s in the UK we can observe the development of small, locally based and locally run (often through volunteers) organisations that were established in opposition to the decisions of the local state. This idea of being 'in opposition to' the local state and/or local decision makers is important. Those defined as local decision makers included heads of schools or town planners or heads of public housing departments, as well as political representatives - councillors or senior local politicians.

There is a very rich tradition of community activism in the UK and activist-led initiatives within neighbourhoods that challenged the authority and power of either local political elites or those who managed social and welfare agencies. While some of these initiatives may have developed into national organisations over time it is important to locate their origins within this framework of 'opposition to' the state rather than how we can describe many of the other models as being 'compliant with' or 'conforming to' the needs and values of the state (Birch and Whittam, 2008; Craig and Mayo, 1995; De Filippis et al., 2010; Evans, 2007; Purdue et al., 2000).

This political and historical framework is important too because it provides the basis for a chronology that reflects the politics and the politicisation of the VCS in the UK as well as attempting to locate this discussion within a framework of state and civil society relationships. The key theoretical and political concepts that are important here are those that relate to the ideas of neoliberalism. The significance of neoliberalism is explored below. But, it is helpful to make the point that the success of neoliberalism in shaping the remaking of social and welfare policies in the UK (in particular), as well as economic policy has itself influenced concepts of 'leadership' and governance across the public realm. It is here too that we can observe the relationship between both neoliberalism and the VCS and between neoliberalism and those who 'lead' the sector.

What is significant (for this writer) is how the language and ideas of those associated with progressive social change: empowerment, civil and political rights, politics of identity, participation and accountability, as well as partnership and collaboration have themselves been colonised and appropriated by the New Right. In addition, the language and ideology of neoliberalism provides a counternarrative of personal and individualised stories as a counterpoint to those that are rooted in a class or collective interpretation of society and the struggles within and between the powerful and the disenfranchised (De Filippis et al., 2010; Harvey, 2011, see 253-259).

The discussions and explorations of the ways in which the concept and practice of 'leadership' of the VCS in the UK developed draws upon different and often contradictory traditions. These traditions, which are examined below, reflect quite 
different sets of values and motivations; they also reflect (or illustrate) different ways of constructing and understanding concepts of accountability and representativeness, and the different ways in which the social relationships between those who are the organisers are constructed with the organised. Indeed, the critical dynamic present within the VCS is how the relationship with the state is framed and understood.

\section{New professionalism and the voluntary and community sector}

Within this broad ideological framework of neoliberalism we can see too how it has shaped ideas of professionalism and professional practice stretching from and including: ideas of communities of practice to being critical reflective practitioners. The notion of professionalising the VCS is a key political concept, as well as being offered as a neutral or strategic goal for those who manage VCS organisations. The concept of 'new professionalism' in the UK has its roots in the 1980s as part of the welfare and social policy changes introduced by the New Right in the Thatcher/Major Conservative governments. Following the election of the New Labour government in 1997 it formed an important element in their justification for and promotion of the reorganisation of those agencies and professionals working with children and young people. But, it had been present - as an organising concept - prior to the election of a New Right government in 1979. It is this development that might now be seen prefiguring the contemporary debates on leadership within the VCS that the chapter examines.

These approaches, shaped as they are by the ways in which the 'world-view' of the organisation has been framed, often stand in opposition to those groups that have constructed a quite different 'world-view', one that might be based on the needs of specific groups of individuals or a specific locality or place. Many community-based organisations are established to meet the needs of individuals defined by their sense of place or locality. Here the idea of 'community' is much more about a sense of place or neighbourhood - it has an explicitly spatial or physical dimension to it (Chesters, 2010; Filkin et al., 2000; Foley and Martin, 2000; Hay, 2008; Jowitt and Chapman, 2001; Kohler and Wissen, 2003).

Through these two quite separate senses of what the geography of the VCS means and its scale we can see how different models of leadership and decision making emerged and became part of the organisational culture and practice. In these two examples one can imagine the organisation influenced by faith and religious groups seeking to develop a decision-making structure that is focused on the external (and the global) and that the ethos of the organisation is to be found in its work with individuals at risk and vulnerable. We might anticipate an explicitly ethical framework for their campaigning and lobbying.

In the localised and small-scale context we might anticipate seeing evidence of models of decision making and leadership that reflect the small-scale and potentially insular nature of community-based organisations.

The ir diverse $\mathrm{b}$ idea of ' $c$ counterw represent their rela critical si way thesi challengs maintain their mer

From $t$ emerged primary 1 emerging New Lab ment repı

The 19 deprivati, Welfare Programr included: working-। attainmer levels of

These funded ag to work v 1960s, wl forty yeal economic industrial

These , the shift (' to yet anc as well. I layer of $\mathrm{V}$

We can to the rest welfare pr It was in leadership It is the in occupying 
) different epresentareen those he critical is framed

oo how it from and ztitioners. 1 as being nisations. 1980s as sht in the the New tification essionals rganising It is this bates on

Id-view, z groups sased on e. Many lividuals is much satial or Martin,

he VCS lecision stice. In tith and focused e found pate an

ence of sle and
The intellectual, social, ethical and political roots of the VCS in the UK are diverse but they do offer a way of understanding their broader contribution to the idea of 'civil society' and the ways in which their presence represents an important counterweight to political institutions, as well as those of the state. In a sense, they represent a tradition of independent action and separation from the state. From their relative independence of the state and civil society institutions they can offer critical support or critical opposition to public policy decisions or practice. In a way these competing positions (support and opposition) illustrate one of the many challenges for VCS organisations, their membership and their leaders: how to maintain distance and independence and at the same time seek to both represent their members and influence governmental policy?

From the late 1960 s onwards we can see how different patterns of relationships emerged and developed over time. This chapter argues that, in the UK, this is the primary period of change and transformation within the Sector in terms of an emerging leadership. As we show below the secondary phase took place under New Labour from 1997 - 2010 and the tertiary phase with the Coalition government represents another shift in the relationship between the Sector and the state.

The 1960s in the UK mark the development of a response by the state to urban deprivation and a perceived weakness of the postwar settlement with regard to the Welfare State. The introduction by the then Labour government of the Urban Programme can be seen as a direct response to a number of urban 'problems'. They included: migration and a response to the conflict and disaffection in urban white working-class areas; a recognition that the welfare state had not 'solved' poor attainment in schools; bad housing and its links to ill health; and a persistence in levels of poverty too.

These 'urban' or city issues also highlighted the apparent failure of those statefunded agencies to provide the required intervention into deprived neighbourhoods to work with individuals and families. In a very real sense the crisis of the late 1960s, which gave rise to the Urban Programme, pre-figured the crises of the next forty years as urban areas underwent profound change as a consequence of the economic, industrial and spatial restructuring of the more mature advanced industrial capitalist economies of northern Europe.

These crises included not just a reaction to rising levels of unemployment or the shift (over time) from an industrial economy to a banking and service economy to yet another period of disruption from 2007 onwards, but also a political crisis as well. The form this crisis took revealed the relative weakness of the existing layer of VCS leadership as they too had to respond to these crises.

We can place the Urban Programme in the UK as part of a generalised response to the restructuring of industrial areas and of a need to address gaps in social and welfare provision. It was not about developing a sustainable response to the crisis. It was inevitably reactive. The state did not regard the VCS as offering local leadership over the long term. The VCS were marginal to the needs of the state. It is the impact of neoliberalism that repositions certain elements of the VCS into occupying key roles in the management of the crisis. As a consequence, there is 
a need to develop a longer-term strategy for some VCS agencies. The Urban Programme (together with funding to support local government in meeting the needs of a more racially diverse set of communities introduced in 1966) funded a number of initiatives and projects designed to respond to the needs of those communities affected by the social and economic changes. Over time, the Urban Programme shifted its focus in response to different priorities set by government but a core part of its activities was the funding of information and advice agencies, legal aid units, resident and tenant associations, and activities or projects designed to meet the needs of children and their lone parents.

In the USA the War on Poverty programme was established with very similar aims and remit. There was a shared expectation that these programmes would encourage the participation of users and residents too. In the context of the resistance to the war in Vietnam and the Civil Rights campaign and the Feminist Movement - the impact and legacies of which stretched across the Atlantic - we can see how these developments impacted upon the VCS in the UK (Beauregard, 2003; Medoff and Sklar, 1994; Munro et al., 2008; Yin and Yates, 1975).

The scale, capacity and politicisation of the VCS were all directly affected by these changes. The Urban Programme felt the consequences of both drawing the local VCS leadership into the sphere of influence of the state and of facilitating directly the politicisation of activists within the VCS or of individuals who became involved in the VCS.

The Urban Programme was one of many regeneration initiatives funded, managed and led by successive political administrations from 1969 to the present in the UK. While the priorities and funding levels were set at the centre and approved by ministers, it was at the local (city) level that responsibility for their administration and delivery were delegated. One consequence of these developments was the emergence of a cadre of VCS activists who became expert in understanding government funding requirements and policy initiatives, and over time were able to anticipate new areas for development. Many of these individuals were active in the new pressure groups and campaigning bodies set up in response to the welfare crisis itself of the 1960s. They reflected concerns over housing and child poverty, as well as the growing campaigns against racism and for equal pay. Some of these activists had been involved in faith and church groups and a number were active in the trade union movement too. Another layer came from the students' movement of the late 1960s, politicised as a result of opposition to the war in Vietnam or through the wave of occupations in higher education institutions from 1968 onwards. What is fascinating to reflect upon, over forty years later, is the strong emphasis there was on social responsibility and ethical practice across these different pathways into the more radicalised model of the VCS. Such an approach is in direct conflict with the needs and values of neoliberalism.

This shared sense of practice and the values that shaped it were critical factors in influencing the leadership models that emerged over the next decade. It is important to note that the diverse VCS in the UK with its well established welfare institutions (for children and the most vulnerable) rooted in the previous century

and

indu

a dif

$196 C$

elem

ethic

are $\mathrm{F}$

It

activ

leads

with

a $\mathrm{co}$

coop

unior

nego

One

there

instit

A

the $\mathrm{g}$

in yo

open

intell

the is

challı

withi

$\mathrm{Th}$

cours

acade

gram

upon

to thi

chari1

an al 1

Fund

value

comn

Th

conte

in wl

econc

natior

event:

gener 
Urban ing the funded $f$ those Urban rnment encies, ssigned

similar would resistminist c - we 'egard,

ted by awing itating ecame

Inded, resent e and their levelert in l over duals sonse $\mathrm{g}$ and I pay. num$n$ the o the tions er, is cross h an

ctors It is lfare itury and funded via the Church, or through the charities established philanthropic industrialists, continued. At different times over the next thirty years they occupied a different political 'space' from those drawn from the activist movements of the 1960s. At times they were to find themselves supportive of the more radicalised elements in the VCS and oftentimes they drew back. As we will see, their social, ethical and faith-based practice has proved to be a significant factor in how they are positioned today.

It is important to reflect upon the extent to which the radicalisation of these activists was significant in relation to their membership of the VCS and the leadership roles they took on. The traditions they came from and the environment within which they were active suggested that they were much more likely to adopt a conflictual model of relationships with the local state than a consensual or cooperative model. Indeed, we could assume that those who came from the trade union movement were more likely to look for consensus and agreement (after negotiation) than those who came from an activist or campaigning background. One of the key differences between these two traditions was the extent to which there was a shared analysis of the state and how power is exercised through institutions of the state.

A parallel development to this period of change in the late 1960 s in the UK was the growth of higher education and the increase in provision for those involved in youth work, social work and education. These programmes were, themselves, open to influence from professionals who were also practitioners or activists. The intellectual and political context to these programmes of study were places where the idea of the state being a neutral agent in the distribution of resources was challenged and deconstructed to develop possible alternatives to the social relations within society.

The curriculum, teaching and learning, and assessment strategies of these courses were, in many instances, influenced by a range of critical thinkers, radical academics and practitioners. From the late 1960s to the mid 1980s these programmes provided a practical as well as intellectual 'space' within which to reflect upon power, inequalities and social change through collective action. In addition to these influences, these programmes reflected the concerns of international charitable organisations that sought through their work in the Third World to model an alternative to that offered by the World Bank or the International Monetary Fund. In particular, these organisations were often very explicit about the ethical values that underpinned their work and their wish to work with local groups and communities rather than impose an externally set agenda.

There were, of course, many tensions and difficulties to negotiate in these contexts. A key part of the tension was the impact of the Cold War and the way in which the Third World became an extension of the political, military and economic conflict between East and West. The Vietnam War and the many other national liberation struggles in Africa and Latin America were significant political events and they exercised an important degree of influence over at least one generation of practitioners working at home and abroad (Gaynor, 2010). 


\section{John Diamond}

\section{Towards an alternative social and economic policy}

The development of the VCS from the mid 1970s to the mid 1980s marks an important point of transition for those individuals and organisations who defined themselves as oppositional to the state and who were seeking to develop a more radical neo-Marxist critique of power and politics. The transition was not a single event - rather, it was a process. The decade from 1975 to 1985 in the UK was a highly political period. It started with the Labour government introducing cuts in social and welfare spending which was met with opposition from the trade union movement as well as community-based organisations and groups. The election of the Thatcher government in 1979 saw a continuation of the cuts programme. This period, also, saw significant rises in unemployment and a global recession too. It also saw a major confrontation between the Thatcher government and the Miners Union which lasted for a year and ended with the defeat of the miners and, perhaps, marked a high point for neoliberalism in the UK (Burns et al., 1994; Diamond, 2002; Diamond and Nelson, 1993; Harvey, 2005; Stoker, 1994, 1996).

These events are important and, indeed, this decade is perhaps one of the most important in UK postwar history. As well as these changes, developments, and social and political unrest there was another important political project underway at local authority level.

The cuts introduced by Labour in the mid 1970s were seen to contribute to their defeat in 1979. In an attempt to revive the Party nationally there was a serious attempt by different groups on the Left to revive and reform local government. This period of change - sometimes described as 'going local' - brought together a broad left alliance of trade union activists, community activists, elected politicians and single issue campaigners. Their story - of how they attempted to transform local politics - is an important part of the development of the VCS in the UK. While they were mainly concentrated in the urban centres of the UK and the big cities (hence their descriptor as the New Urban Left) they drew upon many of the practices and politics of the VCS. In many important ways, this was the 1968 generation of community and political activists and while they looked to public sector trade unions for support they were not of the trade union movement.

To the extent that they had a shared philosophy or political programme, they focused their activity on a limited number of very important areas: equalities and anti-discriminatory practice - especially with regard to gender, race and sexuality; tenant and resident participation - through devolved budgets and decision making at neighbourhood level; an alternative economic policy - to counter the New Right marketisation of the public sector that was emerging under Thatcher; and a commitment to more inclusive politics and participation at the neighbourhood level. This move to decentralised decision making and also to create a more pluralistic form of politics was highly significant. It was an attempt - so it was argued - to demonstrate that Labour was a left-of-centre party who could govern well (at the local level) and so deserved the voters trust.

This period of developing an alternative to the New Right did not last beyond the mid 1980s. The defeat of the Miners Strike marked a profoundly important

mon

too

com

start

govi

the

com

racis

soci

T

whis

sepa

oper

on $c$

muc

auth

wer

and

loca

quo.

was

man

$\mathrm{T}$

in $\mathrm{U}$

and

an ir

in tr

prof

elen

itsel

role!

exp€

1981

First

by $\mathrm{t}]$

size

polit

is le

a nu statu of th 
marks an ho defined op a more ot a single UK was a ng cuts in ade union lection of nme. This ion too. It le Miners , perhaps, Jiamond,

the most ents, and nderway

e to their I serious arnment. together liticians ansform the UK. the big $y$ of the le 1968 , public it.

ie, they ies and suality; naking $\checkmark$ Right and a irhood I more it was jovern eyond ortant moment for the organised Left in the UK. But, there were significant consequences too for the VCS. The broad alliance of individuals, single issue campaigns and community activists who had become part of this alternative to the New Right had started to move (physically and intellectually) across to posts and roles in local government. The individuals who took up the jobs and roles most associated with the New Urban Left reform programme often had a shared background in community activism or were leading members of the Women's Movement or antiracist campaigns. A number of them too came from working overseas as part of social, political and faith-based initiatives.

There is an interesting and important discussion here in terms of the extent to which we understand the concept of 'leadership' and leadership roles to be separate from the aims and values of the organisation within which individuals operate. Those individuals who had come from a VCS background or had worked on development initiatives overseas or were political activists were likely to be much more politically aware than conventional local government officers. In urban authorities in the early 1980s the promotion of equality and social justice projects were often led by individuals who came with a set of highly developed political and organisational skills, formed by their work in these areas. Their presence in local government was seen as representing a disturbance or dislocation to the status quo. The traditional model of 'detached' local government officer/administrator was being replaced (or at least challenged) by an activist/advocate model of manager/officer.

Thus, while there was an idea of a commitment to the concept of 'public service' in UK local and central government administration, the influx of VCS activists and members changed both the tone and the content of this concept. There was an important theoretical and conceptual debate taking place between those involved in the education and training of social, health and youth work practitioners and professionals and the user or service groups they were working with. While a key element in that intellectual debate focused on critical and reflective practice it was itself informed by ideas of decision making, leadership styles and management roles. More significantly, for this author, these debates were informed by the experience of participants as activists and managers working in the field.

There were, however, two separate but interrelated developments during the 1980 s that changed the context within which these debates were taking place. First, the political period after the defeat of the Miners from 1985 to 1992 is marked by the Conservatives winning two more general elections and second, the scale, size and activity of the VCS continues to grow. While the former sets the national political tone, the latter has a much more direct impact upon the way the sector is led.

By the end of the 1990s the VCS is seen as a key partner and provider across a number of welfare and public services. This represents an important shift in the status of the sector but also leads to an important change in the way the leadership of the VCS is seen and how they believe they should be seen.

One important consequence of both the growth of the sector and the move by individuals across from the VCS into local authorities is that increasingly VCS 


\section{John Diamond}

organisations look to City Hall for advice, guidance and strategic leadership. There is a symbiotic relationship between City Hall managers and politicians and a number of key VCS organisations or coordinating bodies during this period. The members of VCS management boards or trustees are often key political leaders or managers from City Hall. As central government funding during this period required VCS participation (often in a passive way) it was important for City Hall officials to maintain good lines of communication with local VCS leaders and vice versa (Bassett, 1996; Bennington et al., 2006; CSC, 2010; DeFilippis et al., 2010; Hoggett et al., 2009; James and Cox, 2007; Leach and Wilson, 2000; Pearce, 2010; Peck and Tickell, 1995).

The overlapping membership of political groupings as well as of single issue campaigns by VCS leaders and activists and City Hall officers meant that there was a blurring of roles and boundaries. In a quite important way we can see that by the late 1990s in the run up to the election of New Labour these different groups of professionalised activists and managers operated as one large group with interlocking and overlapping membership.

We can see (as Harvey 2011 argues) that these relationships form a very important part of maintaining (and sustaining) the values and needs of the neoliberal project: these individuals had become an important reference group for each other; through their roles and functions they share similar values and assumptions. They have become detached from their constituencies as they have become increasingly professionalised and de-radicalised and they have/had become over-dependent on state funding. It is important to note that while this process has taken place over time it mirrors the experiences of the trade union movement. Within the trade unions it is possible to observe how the growth of the unions and the increase in the number of full-time officials has been attributable to a decline in radicalism and independent action. There is no real equivalent in the VCS of the shop stewards' movement, which has oftentimes been the site of unauthorised activity (by full-time officials). Arguably, the nearest equivalent would be the local infrastructure organisations that have developed over time as places of expertise and knowledge on funding and policy matters.

By the end of the 1990s the VCS in the UK had become an important part in the mixed provision of social and welfare services and they were increasingly being used by the state to act as referral agencies for a range of educational and welfare initiatives aimed at working with the 'hard to reach'. In a sense, significant parts of the VCS had moved from campaigning and political reform/lobbying to providing necessary support for the most vulnerable. In effect, they had become part of the mixed economy of welfare provision and, from the state's point of view, a necessary part of their social and economic policies.

In addition, as a consequence of these developments and changes but also as part of the broader pattern of interconnecting networks and social/political relationships between community activists, welfare-state professionals and leftof-centre political activists, as well as social democrats, there was an emerging literature and practice that highlighted leadership within the VCS as a priority for

develo] traditio

From and th

The ele in the $\mathrm{r}$ in revi promot econon While 1 for $\mathrm{VC}$

The 1 activity projects state's 6 of a $m$ instituti of ident

Thes: VCS in as part involve the VC: importa ways in hand $d \epsilon$ dimensi fundam organise were en the day Alongsi ways in rewarde

In ads Renewa - the c1 Partners to be ev: from the agencies VCS we 
development. As is discussed below, these developments sit within the neoliberal traditions: individualistic, detached and consensual but within a particular narrative.

\section{From New Labour and the third sector to the Big Society and the age of austerity}

The election of New Labour in 1997 marked the beginning of an important shift in the relationship between the VCS and the state. It is this shift that is so evident in reviewing the various leadership initiatives that the Labour government promoted and sponsored. The 'shift' can be understood by reference to the social, economic and political context within which New Labour framed their priorities. While New Labour claimed to be supporting the idea of a 'sustainable' approach for VCS leadership, in practice this did not happen, as is discussed below.

The place and role of the VCS moved from being a peripheral part of the state's activity - direct funding through central government grants to local and specific projects or initiatives aimed at particular vulnerable groups - to being part of the state's core activity. This change, which New Labour accelerated, represented part of a more general restructuring of the state's relationships with civil society institutions and organisations. It is this restructuring that has resulted in new ways of identifying, supporting, promoting and sustaining the leadership of the VCS.

These processes of restructuring included the 'buying' of the leadership of the VCS into the structures, agencies and organisations that New Labour introduced as part of their modernisation reform agenda. A significant part of this process involved a number of significant social and welfare policy initiatives in which the VCS were seen as a strategic partner. These reforms and programmes were important in a number of respects, and they included a key set of changes to the ways in which services for children and young people were organised. As a shorthand descriptor, the 'Every Child Matters' initiative illustrates the scale and dimensions of the reforms introduced. Every Child Matters represented a fundamental reassessment of the way children and young people's services were organised, programmed, managed, developed and funded. VCS organisations were encouraged to offer services before schools opened and after they closed for the day as part of a holistic provision for parents, carers and their children. Alongside the preschool initiative - Sure Start - this programme challenged the ways in which service professionals were trained, recruited, developed and rewarded.

In addition, New Labour introduced its National Strategy for Neighbourhood Renewal (NRS). The NRS together with two separate but interrelated initiatives - the creation of Community Empowerment Networks and Local Strategic Partnerships in the eighty-eight most deprived authorities in England - were seen to be evidence of their commitment to change. The expectation was that leaders from the VCS would sit on the LSPs alongside political leaders, heads of public agencies (including the police) and the private sector. In both developments the VCS were seen as key agents in these change processes and initiatives. The new 
government also put resources into a number of projects aimed at developing, enhancing and sustaining the leadership capacity and potential of the sector.

These changes need to be seen in context. Before 1997 the sector had been essentially a lobbying and campaigning sector. There were a number of health, housing and welfare services that the VCS or the charitable sector provided. The expectation by the New Right was that this proportion of activity funded by the state but delivered by the VCS would grow. As a consequence (and over time) it was likely that the critical voice offered by some elements of the VCS to the activities of the state would diminish or indeed be silenced. As Parkes et al. (2004) suggest, "to the extent that state funders were dictating their agendas, the contribution that VCS could make as alternative voices was being increasingly compromised' (Parkes et al., 2004: 319). This view is shared by DeFilippis et al. (2010) in their reflections on the experiences in the USA, UK and Canada.

The regeneration experience provides a really rich source of empirical data from which we can reflect upon these initiatives. The scale of the urban regeneration programmes and the creation of a civil society infrastructure to sit on partnership boards, play a role in contributing to programme assessments, evaluations and capacity-building developments within neighbourhoods required a sub-structure to support these developments. This sub-structure was often made up of residents and community activists and their energies were directed from activist oppositional politics to consensus building and social regeneration.

The language of partnership and engagement that New Labour offered as an alternative to the rhetoric of the New Right did not, for some, conceal its continuity with the present. The influence of neoliberalism on the New Labour project was evident in a number of ways. And, for the purpose of this chapter we can see it in the model of leadership promoted within the VCS. The growth of the large charitable sector as a service provider commissioned by the state to provide specific services meant that this sector needed to look to its own reference groups for support and professional development. The VCS, with its origins in grass-roots campaigning, had by the early part of 2001 become drawn into the quite different policy environment of contracts, strategic planning and performance indicators. In this context participants were being asked to adopt consensual and pluralist ways to reach decisions. Over time, I suggest, their capacity to adopt more critical or radical positions became lessened. The tendency was to arrive at 'joint' decisions because they were part of the 'partnership'.

The scale of the banking and finance crisis permeates all aspects of contemporary civil society. The impact of the cuts in public expenditure for the VCS are still difficult to quantify precisely. We can speculate on their impact and we can, also, assess the likely consequences for organisations of the severe cut in grant funding and income to the sector over time.

We know that there have been significant cuts in the spending by central government on the infrastructure organisations that have developed over the past thirty years to support the VCS. In some cases these organisations have cut more than 50 per cent of their jobs. These organisations worked at a city or regional or national scale. The loss of jobs and funding on such a scale has real implications 
sloping, or.

id been health, ovided. ıded by rr time) i to the (2004) as, the isingly $\mathrm{s}$ et al.

a from sration tership ns and ucture idents itional as an inuity st was e it in large ,ecific os for -roots ferent ators. ways zal or sions for their medium-term future. It is possible that by 2015 a whole generation of future leaders of the VCS will have been lost. The posts and individuals going include people working on policy development and analysis; funding and strategic planning; equalities and diversity; capacity building and staff/personal development; and those with a senior or strategic role in the leadership and management of agencies based in the sector. These skills and capacities were considered a necessary part of the web of networks and partnerships that made up the public sector reform agenda of New Labour. It is important to place these initiatives and the priorities that stem from them in the other changes they introduced to the regional administrative and political architecture.

New Labour sought to create a national policy and economic model in which, while there was limited devolution to the English regions and the nation-states, there remained a high level of centralisation. In order for the VCS to influence policy decisions, or to seek to claim that they could, they needed to have a presence within these new geographies of place, scale and function. At the level of the English regions, a number of quasi-regional networks seeking to represent the sector emerged. In part, these different agencies reflected different priorities of government or they were the creation of particular funds from central government. An important consequence of the New Labour attempt to re-imagine the boundaries between the public and not-for-profit sector through commissioning services or through multi-agency initiatives or urban regeneration programmes was the institutionalisation of competition between different VCS organisations.

This process of competition was evident over who spoke for the sector in public events or through particular consultation exercises. The form that the competition took varied and included competition in terms of democratic legitimacy - whose 'voice' was being heard. In these settings the competing groups would argue over the extent to which they had a 'mandate' to be heard. A second form whereby this competition could be experienced was through the extent to which different groups could claim expertise and knowledge through direct experience and, as a consequence, that their experience justified their leadership role. Finally, another form that this competition took was when different VCS infrastructure bodies identified with particular places (Manchester vs Liverpool) or when they reacted negatively to those bodies that sought to offer a regional perspective rather than a local or subregional account.

In these ways we can see how such infrastructure bodies aligned themselves with the interests and values of a quite narrow set of decision makers. Their reference group became the city or regional public agencies or political elites, not their membership. Such infrastructure bodies became over-dependent upon central state funding and, arguably, became more focused upon securing the next round of funding than looking at a broader - and strategic - framework.

We can see through the lens of neoliberalism that the state incorporated or coopted the VCS into their strategic goals and objectives. New Labour represents an important phase in that process of co-option. As they allocated funds to invest in the capacity building of the sector they developed a significant cadre of VCS professionals who occupied key political as well as ideological roles in guarding 
access to the services and funds available. The development of support for those who occupied important leadership roles in the sector can be seen through the categories shown in Table 5.1.

In a real sense the investment by New Labour in the skills and capacity of the sector to become an essential part of the partnership and joint working approach to public service reform will be lost. Arguably, the present UK Coalition government does not value many of those skills and capacities identified above. Indeed, there are some really important differences between New Labour and the Coalition.

In Table 5.1 the different categorisations are presented alongside a number of policy and practice initiatives that New Labour and the current Coalition government have endorsed. As the table suggests, there is a real dichotomy between those categorisations that reflect an explicit political or ideological stance and those that might be described as managing the relationships between the state, the market and the individual.

Over the past thirty years the state, through direct funding or through alliances with the charitable sector, has invested resources to support the capacity building and development of those it considered to be the 'leaders' of the VCS. The Clore Social Leadership Programme (Hopkins, 2010: 14) outlines their analysis of the issues facing current and future leaders in the sector:-

- Organisational profile of the sector $-33 \%$ of organisations have fewer than 10 employees;

- Workforce is growing and professionalising;

- Increasing role in providing direct services;

- Diversity of the Sector adds to its complexity.

These priorities and the way the needs of the sector are framed rule out certain models of leadership. The analysis outlined above throughout this chapter argues that the tension between 'managing' the sector or 'leading' the sector requires more than an assessment of needs. The tensions explicit in the story of the VCS in the UK over the last thirty years are best understood in terms of the politics of the Sector and the relationship(s) between the state and civil society.

Table 5.1 offers one way of capturing the different organisational forms present across the VCS in the north-west of the UK and it seeks to interpret the leadership and decision-making models within the differing categories. An important dimension of the descriptors offered is the distinctions they offer in terms of the 'political' nature of the relationships within the individual categories.

One of the significant conclusions drawn for this chapter has been the reemergence of a highly politicised and engaged element within the VCS. As Table 5.1 suggests, this development has its roots in the anti-globalisation movement of the latter part of the 1990s and the anti-war movement that developed in response to the invasion of Iraq. In the UK these developments drew together quite different traditions in the VCS. A significant part of this movement is made up of former political activists influenced by the Marxist and Trotskyist movements of the

Social Er

Brokers : Fixers

Network

Independ

$1970 \mathrm{~s} / 1$

and the by an eq movem tend to :

A thi practice the loca above grouped the Nati informa

In $\mathrm{m} \varepsilon$ presente provisic ments si with the and org They of and tho highly c 
Leadership and the voluntary and community sector

Table 5.1 Activists - models of organisation, attachment to values and ethical practice

\begin{tabular}{lll}
\hline Category & Models of organisation & $\begin{array}{l}\text { Commitment to } \\
\text { social values }\end{array}$ \\
\hline Political/Social & $\begin{array}{l}\text { Systematic; membership based; alliances across } \\
\text { political spectrum; oppositional; campaigning; } \\
\text { non-hierarchical }\end{array}$ & Very high
\end{tabular}
non-hierarchical

ty of

king

ition

love.

and

ar of

'ern-

hose

that

rket

ices

ling

lore

the
Single Issue

Systematic; membership based; thematic; campaigning for changes in legislation; use of legal processes to promote change

Social Enterprise Networked; social media; loose alliances; pluralist; personal relationships and contacts

Brokers and

Fixers

Highly connected through personal/'professional' relationships; use of networks to promote role; highly individualistic

Network

Independent

Service led; responsive to government priorities; innovative in terms of anticipating trends; contract focussed; highly personalised relationships

Re-emerged in post 2001; developed in response to globalisation and war in Iraq; highly politicised Very high

Moderate

Weak

Weak to low

Very high and oppositional; networked

1970s/1980s, active and present with trade unions, anti-cuts initiatives of the $1980 \mathrm{~s}$ and the anti-Poll Tax generation of the early 1990s. But, they have been joined by an equally significant movement of single-issue activists drawn from the Green movement and those committed to social justice and equalities. Both traditions tend to work outside the Labour Party.

A third and important tradition has been those engaged in the education and practice of social work and youth work. Many of these individuals were active in the local government reforms of the 1980 s - the going local initiatives described above - and they too were active in the anti-war movement. These individuals are grouped around the National Coalition for Independent Action and together with the National Community Activists Network they provide an important source of information, debate and organisation.

In many ways these traditions quite explicitly reject the organisational forms presented by the other categories - those involved in social enterprise and service provision or through providing consultancy and advice services. These developments sit within a much newer set of developments which are much more congruent with the values and aims of neoliberalism. They are the pre-figurative structures and organisational forms for a post-local state welfare and social policy service. They offer, too, a set of social relationships based upon dependent relationships and those who work for such agencies represent a new peripheral workforce highly dependent on service level agreements and contracts.

It is in these relationships and in the relationships between those who commission such services that a new politics of contestation and opposition is becoming 


\section{John Diamond}

more evident. In the UK the Coalition's commitment to cuts and a new settlement between the state, civil society, the market and the individual depends upon an enlarged and sustainable VCS. At the same time the opposition to the cuts nationally and locally is part of a broader and global set of conflicts. The scope to develop a new set of political and social relationships is opening up.

\section{Conclusion}

The scale and diversity of the VCS in the UK suggests that it will remain an important agency of the state in the provision of health and welfare services. Indeed, the VCS organisational model of service provider might be seen as an 'ideal' type promoted by neoliberalism: it is non-state funded, receives funding through contracts and the commissioning of services, competes with state funded agencies and other charitable enterprises for work and so through market mechanisms keeps its costs and overheads low by depressing wages and conditions of work and, crucially, secures the depoliticisation of the VCS in a time of profound crisis.

Clearly, this process is imperfect and can only point to emerging (and possibly developing) trends and patterns. But there are three key points for consideration and reflection. First, the scale of the crisis is likely to lead to a major restructuring of the VCS in the UK. It is very likely that within five to ten years a significant number of the agencies now functioning as part of the new social and welfare state promoted by New Labour will be gone - and that we can expect mergers and closures within the sector; second, while there has always been change within the sector - as organisations fail through loss of state funds or through key individuals leaving and moving on - these second tier organisations are seeking to reinvent themselves as social enterprises and we can expect some of them to survive. This is important because they have the potential to provide some of the necessary expertise and social/political 'memory' to act as critical networks supporting and holding together much weaker and more fragile organisations. But, there will be a serious loss of jobs and with it a loss of skills, capacities and understanding; finally, there has been a marked politicisation within some key elements of the sector. This process of (perhaps) radicalisation has been informed by (and is informing) a broader alliance of resistance and opposition to the state and to the austerity proposals.

Why do these changes and developments matter? They point to the ways in which the concept of 'leadership' was understood within the VCS and by New Labour. In a very important sense there was an intended consensus between key New Labour ministers and advisers and leading figures within the VCS, including the large and influential charitable foundations, on what was meant by 'leadership' and what the VCS needed. The initiatives introduced and promoted by New Labour and the charitable trusts and foundations were quite consistent with detaching political questions and skills from the social and economic environment within which the VCS was situated. 
sttle-

The priorities of the large trusts and foundations were to identify those individuals who were already key figures within the sector or who had the potential to be part of the next generation of leaders in the sector. In some respects this way of working is no different from that favoured by large corporations as they select their 'brightest and best' to complete their MBA at Harvard.

As this chapter has sought to discuss, the politics and ideology of neoliberalism are central to developing a full understanding of how the concept (and practice) of leadership within the VCS was understood and enacted. A key part of this discussion has been the different organisational forms that developed within the VCS over time and how these required different leadership models and ways of working. But, the primary change that took place over this thirty-year period (or over one generation of practitioners and activists) has been the shift from political activist to social entrepreneur or service provider. It is this journey that illustrates the significant changes in the social and political environment of those who occupy key leadership roles in the VCS.

The interesting and exciting changes that are evident in the UK and across the world are the parts played by non-aligned activists and social movements. Harvey (2010: 258-259) offers a rich and detailed set of insights into the nature of these diverse movements and notes their contradictory nature as well as the potential that exists within these movements to offer a different set of social, ethical and political values to those cherished by neoliberalism. In a sense the VCS and its diverse set of members/networks offers a possible alternative to that proffered by the state. In the UK this is not a re-run of the mid 1980s when the Miners Union as well as a large numbers of local authorities and many hundreds of thousands of activists provided an alternative social and economic policy and when the defeat of the miners was necessary in order to protect the needs of capital.

The critique offered by DeFilippis et al. (2010: 182) on the future of the sector and the potential offered by community organising - a return to the values and practice of those involved in the War on Poverty in the USA in the 1960s and the Community Development projects here in the UK - put it slightly differently from Harvey. They quote Mary Ellen Lease who, 'working with American agrarian populists, is said to have challenged her fellow history makers to "raise less corn and more hell" ... '. The VCS leadership in the UK need to listen to those from the varied and different networks who are seeking to provide a leadership that brings together an alliance of those resisting the cuts in the tradition of the sector itself - non-aligned, participatory, democratic and independent.

\section{Bibliography}

Balloch, S. and Taylor, M. (eds) (2001) Partnership Working: Policy and practice, Bristol: Policy Press.

Banks, S. and Shenton, F. (2001) 'Regenerating neighbourhoods: A critical look at the role of community capacity building', Local Economy, 16:4 286-298.

Bassett, K. (1996) 'Partnerships, business elites and urban politics: New forms of governance in an English city?', Urban Studies, 33:3 531-555. 
Beauregard, R. (2003) Voices of Decline, London: Routledge.

Bennington, J., de Groot, L. and Foot, J. (eds) (2006) Lest We Forget: Democracy, neighbourhoods and government, London: SOLACE Foundation Imprint.

Birch, K. and Whittam, G. (2008) 'The third sector and the regional development of social capital', Regional Studies, 42:3 437-450.

Blakeley, G. and Evans, B. (2008) 'It's like maintaining a hedge', Public Policy and Administration, 23:1 100-113.

Blunkett, D. and Jackson, K. (1987) Democracy in Crisis, London: Hogarth Press.

Boddy, M. and Fudge, C. (eds) (1984) Local Socialism? London: Macmillan.

Burgess, P., Hall, S., Mawson, J. and Pearce, G. (2001) Devolved Approaches to Local Governance, York: Joseph Rowntree Foundation.

Burns, D., Hambleton, R. and Hoggett, P. (1994) The Politics of Decentralisation: Revitalising Local Democracy, London: Macmillan.

Byme, D. (2001) Social Exclusion, Buckingham: Open University Press.

Chesters, G. (2010) 'Social movements and regeneration', in: J. Diamond, J. Liddle, A. Southern and P. Osei (eds) Urban Regeneration Management: International perspectives, 209-226, London/New York: Routledge.

Clark, J., McHugh, J. and McKay, S. (2011) The UK Voluntary Sector Workforce Almanac 2011, London: NCVO.

Community Sector Coalition (2010) Unseen, Unequal, Untapped, Unleashed: The potential for community action at the grass roots, London: Community Sector Coalition.

Craig, G. and Mayo, M. (1995) 'Rediscovering Community Development: Some prerequisites for working in and against the state', Community Development Journal, 30:2 105-109.

Craig, G. and Taylor, M. (2002) 'Dangerous liaisons: Local government and the voluntary and community sectors', in: C. Glendinning, M. Powell and K. Rummery (eds) Partnerships, New Labour and the Governance of Welfare, 131-148, Bristol: Policy Press.

Craig, G., Taylor, M., Szanto, C. and Wilkenson, M. (1999) Developing Local Compacts, York: Joseph Rowntree Foundation.

Dale, P. (2002) At the Starting Blocks: Community involvement in local strategic partnerships, London: CDF.

Davies, J. (2007) 'The limits of partnership: An exit-action strategy for local democratic inclusion', Political Studies, 55:4 779-800.

DeFilippis, J., Fisher, R. and Schragge, E. (2010) Contesting Community: The limits and potential of community organising, New Brunswick, NJ: Rutgers University Press.

Diamond, J. (1991) 'Community co-option or Empowerment? The role of community based work in decentralisation initiatives', Journal of Community Education, 9:1 10-16.

Diamond, J. (2001) 'Managing change or coping with conflict', Local Economy, 16:4 272-285.

Diamond, J. (2002) 'Decentralisation: New forms of public participation or new forms of managerialism', in: P. Mclaverty (ed.) New Forms of Local Governance, 123-140, Aldershot: Ashgate.

Diamond, J. (2008) 'Capacity building in the voluntary and community sectors: Towards relative independence - limits and possibilities', Public Policy and Administration, 23:2 153-166.

Diamond, J. and Nelson, A. (1993) 'Community work : Post local socialism', Community Development Journal, 28:1 38-44. 
Diamond, J. and Pearce, J. (2010) 'Manchester: Between the grassroots and City Hall participation in the global city', in: J. Pearce (ed.) Participation and Democracy in the Twenty-First Century City, 154-199, Basingstoke: Palgrave Macmillan.

Evans, B. (2007) 'The politics of partnership: Urban regeneration in New East Manchester', Public Policy and Administration, 22:2 201-216.

Filkin, G., Stoker, G., Wilkinson, G. and Williams, J. (2000) Towards a New Localism, London: IPPR/NLGN.

Foley, P. and Martin, S. (2000) 'Perceptions of community led regeneration : Community and central government viewpoints', Regional Studies, 34:8 783-787.

Gaynor, N. (2010) Transforming Participation: The politics of development in Malawi and Ireland, Basingstoke: Palgrave Macmillan.

Harvey, D. (2000) Spaces of Hope, Edinburgh: Edinburgh University Press.

Harvey, D. (2005) A Brief History of Neo Liberalism, Oxford: Oxford University Press.

Harvey, D. (2010) The Enigma of Capital, London: Progress Books.

ddle,

ional

anac

ntial

Harvey, D. (2011) The Enigma of Capital, London: Profile Books.

Hay, S. (2008) Developing Active Networks in Local Communities, York: Joseph Rowntree Foundation.

HMSO (1998) Bringing Britain Together: A national strategy for neighbourhood renewal, Report by the Social Exclusion Unit $\mathrm{Cm} 4045$.

Hoggett, P., Mayo, M. and Miller, C. (2009) The Dilemmas of Community Work, Bristol: Policy Press.

Hopkins, L. (2010) Mapping the Third Sector: Context for social leadership, London: The Work Foundation.

James, S. and Cox, E. (2007) Ward Councillors and Community Leadership: A future perspective, York: Joseph Rowntree Foundation.

Jowitt, A. and Chapman, J. (2001) 'Community leaders and community regeneration: A pilot project for neighbourhood renewal', paper presented to the 5th Learning and Skills Research Conference, University of Cambridge, 6-7 December.

Kohler, B. and Wissen, M. (2003) 'Glocalising protest: Urban conflicts and the global social movements', International Journal of Urban and Regional Research, 27:4 942-951.

Leach, S. and Wilson, D. (1998) 'Voluntary groups and local authorities: Rethinking the relationship', Local Government Studies, 24:2 1-18.

Leach, S. and Wilson, D. (2000) Local Political Leadership, Bristol: Policy Press.

Martikke, S. and Tramonti, S. (2005) Spinning the Spiders Web, Manchester: GMCVO.

Mayo, M. (1997) 'Partnerships for regeneration and community development', Critical Social Policy, 17:52 3-26.

Medoff, P. and Sklar, H. (1994) Streets of Hope, Boston, MA: South End Press.

Munro, H., Roberts, M. and Skelcher, ,C. (2008) 'Partnership governance and democratic effectiveness in community leaders and public managers as dual intermediaries', Public Policy and Administration, 23:1 61-79.

Parkes, T., Taylor, M. and Wilkinson, M. (2004) 'From protest to partnership? Voluntary and community organisations in the democratic process', in M. Todd and G. Taylor (eds) Democracy and Participation, 307-325, London: Merlin Books.

Pearce, J. (2010) 'Co-producing knowledge: Critical reflections on researching participation', in: J. Pearce (ed.) Participation and Democracy in the 21st Century, 34-50, Basingstoke: Palgrave Macmillan.

Peck, J. and Tickell, A. (1995) 'Business goes local: Dissecting the business agenda in Manchester', International Journal of Urban and Regional Research, 19:1 55-78. 


\section{John Diamond}

Peck, J. and Ward, K. (eds) (2002) City of Revolution: Restructuring Manchester, Manchester: Manchester University Press.

Pierson, J. (2008) Going Local: Working in communities and neighbourhoods, London: Routledge.

Purdue, D. (ed.) (2007) Civil Societies and Social Movements, London: Routledge.

Purdue, D., Razzaque, K., Hambleton, R. and Strewart, M. with Huxham, C. and Vargen, S. (2000) Community Leadership in Area Regeneration, Bristol: Policy Press.

Stoker, G. (1994) The Role and Purpose of Local Government, CLD Research Paper 4: London.

Stoker, G. (1996) The Reform of the Institutions of Local Representative Democracy: Is there a role for the Mayor-Council Model? CLD Research Paper 18: London.

Wainwright, H. (1987) Labour: A tale of two parties, London: Hogarth Press.

Wainwright, H. (2003) Reclaim the State, London: Verso.

Yin, R. and Yates, D. (1975) Street Level Governments, Boston: Lexington Books. 
